\title{
Chapter 2 \\ Impact of Building Massing on Energy Efficient School Buildings
}

\author{
Yasemin Afacan and Ali Ranjbar
}

\begin{abstract}
To produce energy-efficient buildings, optimization process for all design stages is necessary. Optimization starts with the massing of the building. This study investigates the impact of the five school massing typologies on energy efficiency: (i) spine/street; (ii) city/town; (iii) atrium; (iv) strawberry/cluster; and (v) courtyard. The chosen massing typologies respond to the question of what an optimum spatial organization of massing is to (i) maximize the use of renewable resources; (ii) utilize thermal inertia of buildings; and (iii) consider the relationship between inside and outside, both existing and future. For each massing type, Sefaira program was used, and simulations were run for annual energy use, annual energy cost and annual carbon dioxide $\left(\mathrm{CO}_{2}\right)$ emissions. The energy use indices (EUI) of the alternatives are around $86 \mathrm{kWh} / \mathrm{m} 2 / \mathrm{yr}$. In the spine massing, the EUI value is much higher than the other four buildings. The highest annual net $\mathrm{CO}_{2}$ emissions are obtained in atrium type of building, which has more floors compared to other massing type. The courtyard type has the most efficient annual electricity cost per area. These findings showed that the goal of the building massing should be not only limited to achieve the low EUI. Thus, this study suggests that an energy-efficient massing should address the questions beyond well-known ASHRAE standards, and define a new holistic model that considers the ratio of surface area to volume more for reducing energy loads than a typical high-performance schools.
\end{abstract}

\subsection{Introduction}

It is an undeniable fact that the built environment is one of the main factors in global energy consumption [1]. So, achieving energy efficiency in current building stocks is crucial because sustainable design, planning, and construction decrease energy consumption by reducing environmental pollution, controlling energy waste patterns, as well as material waste [2]. U.S. Environmental Protection Agency Glossary of

Y. Afacan $(\varangle) \cdot$ A. Ranjbar

Department of Interior Architecture and Environmental Design, Bilkent University, 06800

Ankara, Turkey

e-mail: yasemine@bilkent.edu.tr 
Climate Change Terms defined energy efficient buildings as systems that use less energy to perform as well or better than standard systems [3, 4]. Although rules and criteria for energy efficiency should be decided according to building type and enduse, Jones identified three key points to apply across all building types: (i) maximize the use of renewable resources from wind, sunlight, daylight taking into account the potential noise and pollutants; (ii) utilize thermal inertia of buildings and (iii) consider the relationship between inside and outside, both existing and future [5]. The wide range of assessment systems are also available all over the word [1], such as Leadership in Energy and Environmental Design (LEED) introduced by the US Green Building Council [6], and the Building Research Establishment Environmental Assessment Method (BREEAM) developed by Building Research Establishment (BRE) in the early 1990s as the first assessment method for office building in UK [7].

Both energy use and building first costs are correlated to the efficiency of a building massing, which is measured by the ratio of surface area (envelope) to volume known as the shape factor [8]. Building massing relates to shapes, proportions, layout, interior and exterior relationship and orientation of buildings [9]. The optimal massing reduces energy, eases solar shading strategies and increases effectiveness of natural ventilation $[8,9]$. To produce energy efficient buildings, optimization process for all design stages is necessary [9, 10]. However, architects are still struggling to design energy-efficient buildings, especially in earlier stages of architectural design process, during which building massing is decided [11, 12]. School buildings have some unique features that distinguish them from other typologies [13]. In a school building, occupancy can be very high, reaching up to four times more occupants per square meter than in a typical office building [14]. Moreover, occupants spend much of their time inside classrooms. Because of this occupancy schedule, school buildings require special attention on building environmental quality managements [15]. Although there are numerous studies on the relationship among energy consumption, renewable energy production, and massing [16-20], there is a lack of studies on defining massing based on its relationship with sustainable interior planning strategies. The majority of the articles are focusing on the building geometry solely [21], rather than its close association with interior design parameters. Thus, this present study attempts to fill this gap by studying and comparing five school massing typologies based on sustainable interior functioning in terms of their impact on energy efficiency.

\subsection{Energy-Efficient School Building Typologies}

\subsubsection{The School Typologies}

The typology is the fundamental aspect of the discipline of architecture. It means type, model, and primary form of a building [22]. The type plays a key role in defining 
preconceived entities for the conceptual design process [23, 24]. Graca et al. defined seven school typologies based on solely plan layout; row, double, two sets, two sets of L, U shape, L shape and two sets covered with patio area. They proposed multicriteria optimization for achieving environmental comfort early in design process. Taylor [25] explored impact of school building typologies on visual, thermal, and energy performances by considering three basic typologies; linear, corridor, and concentrated model with different classroom proportions. They observed that compact typologies had better energy performance with heating, whereas linear typologies had better visual performance. So, as stated by Hawkes [26], the compactness of the shape would not be the optimal energy solution for schools.

Quan et al. [27] designed an experimental framework for computing energy performance of four building typologies; pavilion, slabH, slabV, and courtyard. Their results suggested that even with the same typology energy consumption could vary. Zhang et al. [28] studied the thermal performance of school buildings in China by performing energy simulations for eight different typologies; rectangle shape, L shape, $\mathrm{C}$ shape, $\mathrm{H}$ shape, $\mathrm{H}$ shape with atrium, courtyard, high-rise, and irregular shape. Their typologies were derived from geometry parameters based on the number of classrooms, number of stories, window-to-wall ratio and room depth. A key distinction between geometry and massing is the level of input detail, which means that building massing is the overall configuration of the building, whereas geometry is usually originated from proportions of a 2D drawing [21, 29]. So, building massing have not only a marginal effect on floor plan geometries of varying complexity, but also on energy consumption patterns for each interior space [29]. Thus, this study complements other studies in terms of addressing interior efficiency as well by focusing on massing typologies rather than on solely geometry.

\subsubsection{Energy Efficient School Building}

Energy efficient schools aims to open buildings to daylight and views to save lighting energy costs, improve indoor air quality and satisfy user needs and demands [30]. According to Kats, this interior and exterior relationship is not only aesthetically pleasing, but also increases user performance so that workers with views have performed 10-25\% better on tests than those without views [31]. LEED also highlights the connection between indoor and outdoor environments [6]. Designers can maximize interior and exterior relationship through proper decisions on site, orientation, shading structures, interior divisions, glazing and circulation patterns.

Schools in the 1970s were designed with fewer windows, which created dark buildings with extreme opacity [25]. Following sustainability definition by United Nations Brundtland Commission in 1987, UN Commission Report in 1992 on sustainable development and Kyoto Conference by UN Framework on climate change, there were opportunities to discuss how to reduce carbon emissions and improve energy efficiency in buildings [3]. At European level, first action on energy regulation started with European Energy Efficiency Directive in 2002 [32] with a focus on 
optimized design of new buildings and reducing their impact on long-term energy consumption; later in 2012 the concept of Net Zero Energy Building was introduced [33]. This was followed by action in 2018 amending several points of the previous two actions [34]. Thus, school building sector had chance to apply energy efficiency issues after those dates. In Mediterranean region of Europe and in most areas of the world, many school buildings were constructed in the second half of the 20th century so that they fail to meet the most recent criteria in energy efficiency field [35]. There are lots of studies about energy efficiency in school building ranging from passive to active measures. Passive measures focus on building envelope to enhance sustainability through energy reduction in long term life of the building [36], whereas active measures are related to the use of cold and hot water systems, electrical equipment, lighting, heating, cooling, ventilation and air conditioning systems [20]. According to the review study by Dias Pereira et al. it is not possible to have well-specified energy measures for schools since there are uncertainties in energy consumption values depending on the country and location [15]. However, Taylor described the energy efficiency strategy for an ideal school building as a carefully designed physical location composed of natural, built, and cultural parts that work together to accommodate active learning across body, mind, and spirit [25]. Current architecture practices in educational buildings and learning theories are in line with this statement and indicate the importance of environmentally responsive design [37].

\subsection{The Chosen Massing Typologies}

To better understand the significance of interior space organization on building massing, this research differed from the other typology and energy-efficiency studies by choosing the five proposed typologies based on the above-mentioned Jones's three key points of energy efficiency [5]. The chosen massing typologies tries to respond to the question of what an optimum spatial organization of massing is to (i) maximize the use of renewable resources; (ii) utilize thermal inertia of buildings for lighting, heating, cooling, and ventilation; and (iii) consider the relationship between inside and outside, both existing and future. The five proposed typologies are based on architectural design guidelines for schools [38]. The typology classification of this guideline reference is significant because most schools around the world exhibit characteristics of one or more of these five massing typologies. Although there are many local classifications of school typologies in different countries as explained in Sect. 2.2.1, current study defined these five typology alternatives based on a global guide, which "provides an overview of best practices in contemporary school design from around the world, and is intended to serve as a point of departure for architects and owners in the holistic, artistic, and humanistic design of modern educational facilities" [38, p. 6]. (1) Spine/street: In spine massing, major school functions are placed along a central linear space that makes way finding, orientation and access easier. A strong axis could be achieved by placing entrance at one end of the axis. (2) 
City/town: This massing type is defined as a loose type of massing. Classrooms could be located around the main functions, such as library, sports hall, multipurpose room, and cafeteria. This type of massing typology has more potential in terms of legibility and familiarity of facilities, which are essential parameters for considering inside outside relationship. (3) Atrium: This massing suits well for multi-storey schools. A full height atrium has potential to serve for all the three key points of energy efficiency; passive solar design, thermal inertia of the school and also for access outside views. (4) Strawberry/cluster: This massing type is similar to spine type. Like spine massing, there is a central core providing circulation. However, in this typology, classroom and other learning facilities offer more opportunities for passive energy efficiency measures, such as solar gain, shading, etc., and also close student/teacher relationship. (5) Courtyard: Courtyard massing offers flexibility in terms of organizing different functions around the courtyard. Although courtyard massing increases the amount of building envelope, there are many energy efficiency benefits of this type including access to natural light, views, ventilation, etc.

\subsection{Methodology}

To investigate the impact of the five school massing typologies on energy efficiency, in the study, the optimum school massing is assumed a square footage of $1500 \mathrm{~m}^{2}$ with reference of the Advanced Energy Design Guide for K-12 schools [8]. So, the five baseline buildings with $30 \mathrm{~m} \times 50 \mathrm{~m}$ footprint are studied. The climatic location of the study is determined as cold climate, which is Ankara, Turkey, according to ASHRAE 2013 [8]. The five alternatives are schematized in Fig. 2.1.
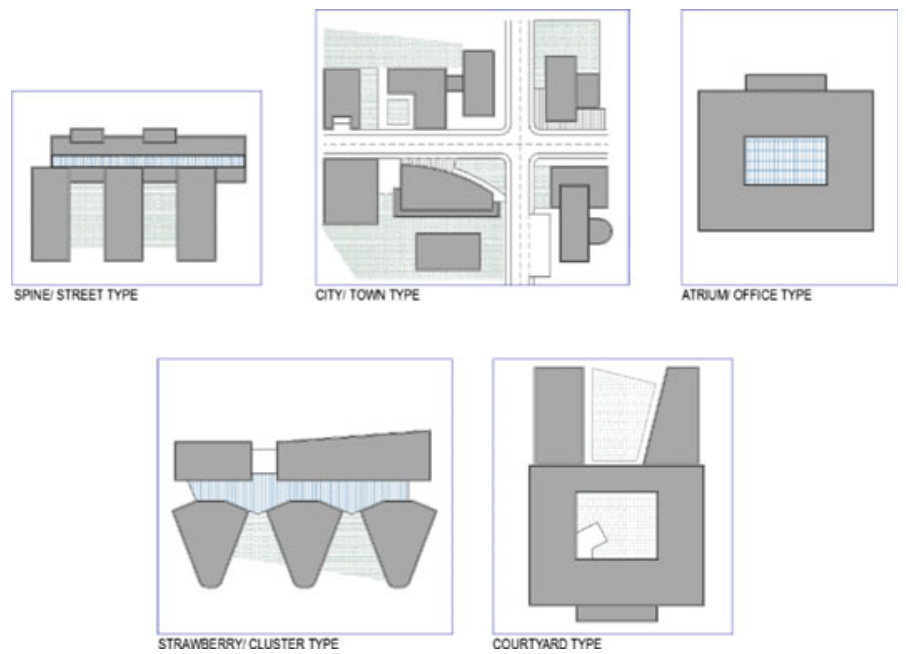

Fig. 2.1 The five school massing typologies 
Table 2.1 Properties of construction of the five school massing typologies

\begin{tabular}{l|l|l}
\hline Building item & Sefaira ID & 203268, Ankara, TR \\
\hline Location-orientation & $\mathrm{deg}$ & \\
\hline $\begin{array}{l}\text { Exterior } \\
\text { wall_Assembly type }\end{array}$ & $\mathrm{W} / \mathrm{m}^{2} \mathrm{~K}$ & $\begin{array}{l}0.17 \\
\text { (U-factor/R-value) }\end{array}$ \\
\hline $\begin{array}{l}\text { N-E-S-W_Facade } \\
\text { glazing }\end{array}$ & $\mathrm{W} / \mathrm{m}^{2} \mathrm{~K}$ & 1.11 \\
\hline $\begin{array}{l}\text { Floors-Assembly } \\
\text { type }\end{array}$ & - & Tiles \\
\cline { 2 - 3 } & $\mathrm{W} / \mathrm{m}^{2} \mathrm{~K}$ & $\begin{array}{l}0.32 \\
\text { (U-factor/R-value) }\end{array}$ \\
\hline Roof glazing & $\mathrm{W} / \mathrm{m}^{2} \mathrm{~K}$ & $2.4(\mathrm{U}-$ factor/R-value) \\
\hline SHGC & - & 0.6 \\
\hline Roofs-Assembly type & \multicolumn{2}{|l}{} \\
\cline { 2 - 3 } & $\mathrm{W} / \mathrm{m}^{2} \mathrm{~K}$ & $\begin{array}{l}0.14 \\
\text { (U-factor/R-value) }\end{array}$ \\
\hline Infiltration-Air changes & $\mathrm{m}^{3} / \mathrm{m}^{2} \mathrm{~h}$ & 7.2 \\
\hline Facade area & \multicolumn{2}{|l}{} \\
\hline
\end{tabular}

Rather than being climate or country based, in this study, the choice of alternatives is based on most contemporary school design from around the world including simplicity, solar potential, natural ventilation, envelope potential to energy usage and strong connections between outdoors and indoors [8]. The variation of shape and form allows to analyze variations in energy performance and $\mathrm{CO}_{2}$ emissions resulted from geometries. The floor-to-floor height of the buildings is set at $4 \mathrm{~m}$, with a floor-to-ceiling height of $2.7 \mathrm{~m}$. The spine massing is one story high. The city, strawberry and courtyard are two stories high, where as the atrium is six stories high. The window-to-wall ratios are set at.\% 30 on each façade. For optimal solar orientation, all the five typologies are oriented such that a rectangular footprint is elongated along an east-west axis. This orientation minimizes unwanted radiation from east and west surfacing, maximizes solar radiation and facilitates shading strategies on the south facade.

The study used Sefaira program simulations to model the five school massing typologies. Sefaira's Real-Time Analysis Plugins, which are dynamic simulation tools for energy assessment based on architecture, lighting, and mechanical systems, use EnergyPlus as their primary simulation engine [29]. EnergyPlus is validated thoroughly and it is distributed free of charge, which makes it one of the most accessible professional energy simulation tools available, such as Design Builder, eQUEST, IDA ICE, etc. [39]. It has been also adapted to stimulate energy balance and thermal comfort of school buildings in different countries, including Turkey [28, 29]. Design parameters in Sefaira's Real-Time Analysis provide constant feedbacks on envelope and material U values. Thus, Sefaira as a validated simulation program has been chosen among other simulation engines. Table 2.1 lists values, which were 
used in the simulation of the five school massing typologies.

The occupancy in the buildings is from 7 a.m. to 6 p.m. on weekdays. Weekends and summer holidays, from 1st June to 1st September, are assumed unoccupied with the primary heating, ventilation and cooling (HVAC) system off. For the HVAC system, fan coil units with central plant system are used. The HVAC system also uses ground-source heat pumps for higher efficiency. It is assumed that there is no hot water demand. Effect of shading by neighborhood trees, buildings and other structures is assumed negligible, whereas there is a self-shading in the massing types. Except the atrium massing type, which has five stories, all the four buildings have two stories.

\subsection{Results and Discussion}

For each typology, simulations were run for annual energy use, annual energy cost and annual $\mathrm{CO}_{2}$ emissions. Table 2.2 lists annual energy use in terms of ventilation, cooling and heating. Annual energy costs and $\mathrm{CO}_{2}$ emissions of the five buildings are presented in Table 2.3. The energy use indices (EUI) of the typologies are around $86 \mathrm{kWh} / \mathrm{m}^{2} / \mathrm{yr}$. Only, the spine has the value of $105.21 \mathrm{kWh} / \mathrm{m}^{2} / \mathrm{yr}$. These values, even the high one, are good values, because according to ASHRAE 2018 Advanced Energy Design Guide for K-12 School Buildings for achieving 50\% energy savings [8], the targeted value for EUI is $104 \mathrm{kWh} / \mathrm{m}^{2} / \mathrm{yr}$ for $4 \mathrm{~B}$ cold climate zone. The reason for these low EUI values is the high performance envelope considering lighting and ventilation. However, it should be noted that in buildings, where daylighting is not as much as available as the others, the EUI is much higher. For example, due to shading of streets in the spine, the EUI value is higher than the other typologies.

According to Table 2.3, the highest annual net $\mathrm{CO}_{2}$ emissions are obtained in atrium type, which has more floors compared to other types. Although this building type is the least efficient in terms of emissions, it is the most efficient massing in terms of annual energy cost per area. This result confirms the idea that compactness of the building shape is ideal for energy preservation [27]. The reason for this emission result is also the high-rise structure of the atrium massing, which reduces the opportunity to use passive solar energy in an integrated manner. However, the low-rise courtyard massing supports this finding by having the most efficient annual electricity cost per area, but lower $\mathrm{CO}_{2}$ emissions. It highlights the importance of daylighting in massing decisions. A properly designed low-rise courtyard could use sunlight to offset artificial lighting loads and save energy. The most efficient annual cooling energy per unit area is again achieved in courtyard type.

Regarding the proportions of total energy use in city and atrium massing typologies, respectively, in the study, city massing type is the most efficient and the atrium type is the least efficient. However, it is seen that the largest load is the interior lighting at about $30 \%$, and the second highest load is the equipment. It is typical for schools with an increased technology infrastructure. When comparing the five alternatives, the heating proportion in annual energy use in spine massing type has the highest 


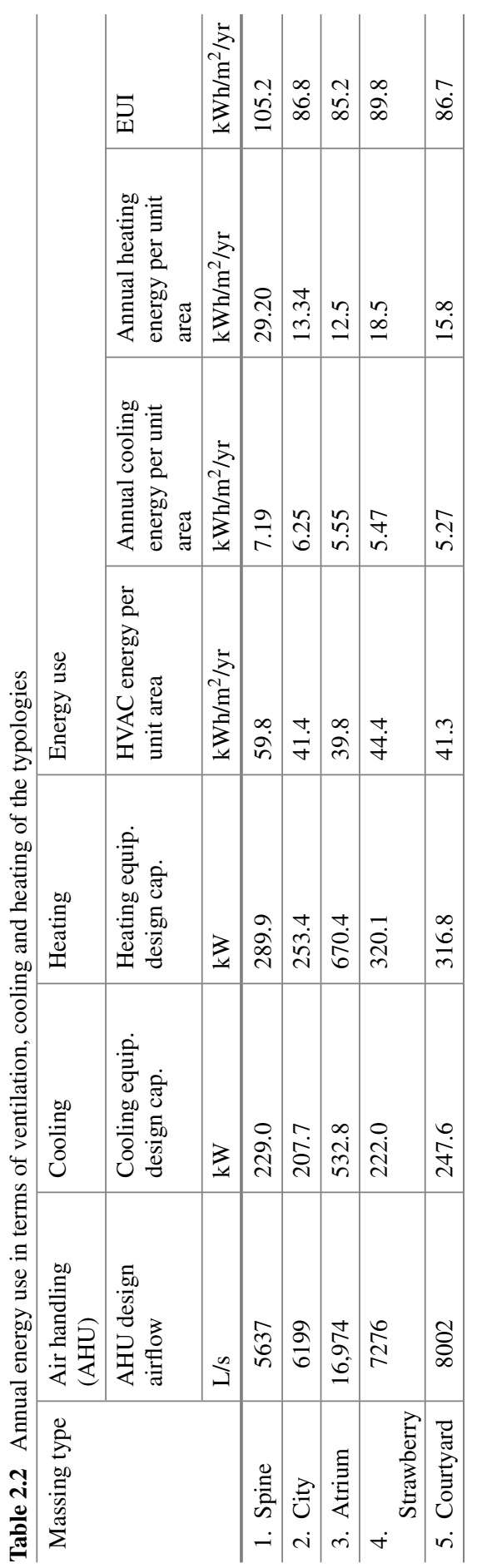




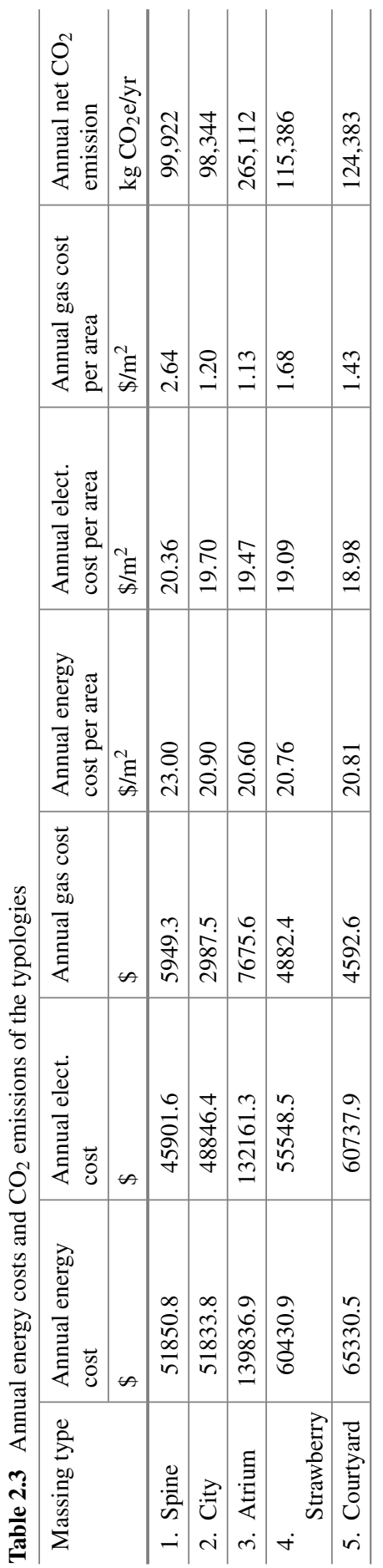


load. The long north facade makes the heating energy more. The largest east façade the school has, the more energy consumption for cooling is required, such as atrium versus city massing. To better extrapolate the findings with the existing knowledge, the annual energy results support the literature [22], and the idea of compactness as the optimal solution for a school typology. However, the simulation results of total energy in terms interior lighting show that the compactness of the shape is not only the optimal solution, because linear typologies would have better daylighting and indoor air quality performance compared to compact typologies. This is also in line with the literature [26], and explains why energy consumption and $\mathrm{CO}_{2}$ emissions are not directly correlated in atrium and courtyard typologies. Moreover, the climatic context of the study is Ankara, Turkey, a cold climate, where lower buildings (2-3 stories) have high annual energy consumption [27]. So, spine massing offered the worst energy performance regarding the climatic context, whereas the city massing has the best $\mathrm{CO}_{2}$ emission performance because of the greater solar gains and less heat dissipation through envelope created by efficient indoor-outdoor relations.

\subsection{Conclusion}

As reported above, knowledge on massing is essential to guarantee energy efficient schools. How a school is shaped regarding the amenities in and out affect the energy and cost of the building. The goal of the building massing should be not only limited to achieve the low EUI. As supported by this study, the massing should be optimized to integrate school's programmatic elements along interior space global performance requirements.

Massing type should be also configured for minimal energy use without neglecting multiple usage and occupancy schedule. To achieve such efficiency, each design decision should have space planning, programming, specifications and installation of proper interior elements in addition to form, orientation, façade design, shading, heating/cooling/ventilation and lighting control. Thus, this study defines massing in schools with an emphasis on environmentally responsible school interior design, which is a comprehensive understanding of high-performance energy efficiency [5]. An energy-efficient massing should address the questions beyond well-known ASHRAE standards, and define a new holistic model that uses the optimum surface to volume ratio of the building more for reducing energy loads than a typical highperformance school. To extend the contribution of this study in design practice and generalize the results, a detailed analysis, where combinations of building shapes, window-to-wall ratio, room depth and orientation parameters, could be performed. In addition, both design and construction of schools should consider the subjective preference of users even during massing decisions. Proper school massing will not only improve energy savings, but also enhance subjective feeling of all users. 


\section{References}

1. Luther, M.B., Rajagopalan, P.: Defining and developing an energy retrofitting approach. J. Green Build. 9(3), 151-162 (2014)

2. Douglas, J.: Building Adaptation. Butterworth-Heinemann, Edinburgh (2006)

3. Appleby, P.: Integrated Sustainable Design of Buildings. Earthscan, London (2011)

4. U.S. Environmental Protection Agency. Glossary of Climate Change Terms (2016). https:// www.epa.gov/sites/production/files/signpost/cc.html

5. Jones, L.: Environmentally Responsible Design: Green and Sustainable Design for Interior Designers. Wiley, New Jersey (2008)

6. LEED. For existing buildings. http://www.usgbc.org/resources/leed-2009-existing-buildingscurrent-version (2009). Accessed 1 March 2015

7. Building Research Establishment (BRE). Building research establishment environmental assessment method (BREEAM). http://www.breeam.com (1982). Accessed 20 June 2014

8. ASHRAE. Advanced Energy Design Guide for K-12 School Buildings. U.S. Green Building Council (2018)

9. Parasonis, I., Keizikas, A., Kalibatiene, D.: The relationship between the shape of a building and its energy performance. Archit. Eng. Des. Manag. 8(4), 246-256 (2012)

10. Dogan, T., Saratsis, E., Reinhart, C.: The optimization potential of floor-plan typologies in early design energy modelling. In: Proceedings of BS2015: 14th Conference of International Building Performance Simulation Association, pp. 1853-1860 (2015)

11. Shi, X., Tian, Z., Chen, W., Si, B., Jin, X.: A review on building energy efficient design optimization from the perspective of architects. Renew. Sustain. Energy Rev. 65, 872-884 (2016)

12. Attia, S., Hamdy, M., O’Brien, W., Carlucci, S.: Assessing gaps and needs for integrating building performance optimization tools in net zero energy buildings design. Energy Build. 60, $110-124$ (2013)

13. Graca, V., Kowaltowskia, D., Petrecheb, J.: An evaluation method for school building design at the preliminary phase with optimisation of aspects of environmental comfort for the School system of the State Sao Paulo in Brazil. Build. Environ. 42, 984-999 (2007)

14. Ching, F.D.K.: Architecture: Form, Space and Order. Wiley, New Jersey (2007)

15. Almeida, R., Freitas, P., Delgado, J.: School Buildings Rehabilitation: Indoor Environmental Quality and Enclosure Optimization. Briefs in Applied Sciences and Technology. Springer (2015)

16. Dudek, M.: The Architecture of Schools and the New Learning Environments. Architectural Press, Oxford and Woburn, MA (2000)

17. Granadeiro, V., Correia, J.R., Leal, V.M.S., Duarte, J.P.: Envelope-related energy demand: a design indicator of energy performance for residential buildings in early design stages. Energy Build. 61, 215-223 (2013)

18. Gratia, E., De Herde, A.: Design of low energy of office buildings. Energy Build. 35(5), 473-491 (2003)

19. Hemsath, T., Bandhosseini, K.A.: Sensitivity analysis evaluating basic building geometry's effort on energy use. Renew. Energy 76, 526-553 (2015)

20. Ndiaye, D.: The impact of building massing on net-zero achievability for office buildings. Build. Simul. 11, 435-448 (2018)

21. Jaeger, I., Reynders, G., Ma, Y., Saelens, D.: Impact of building geometry description within district energy simulations. Energy 158, 1060-1069 (2018)

22. Montenegro, E., Potvin, A., Demers, C.: Impact of school building typologies on visual thermal and energy performances. In: Proceedings of the 28th International Conference on Passive and Low Energy Architecture, Lima, Perú, pp. 2012-2017 (2012)

23. Schneekloth, L., Franck, K.: Ordering Space: Types in Architecture and Design. Van Nostrand Reinhold, New York (1994)

24. Crowe, N.: Studies in typology. J. Archit. Edu. 38(1), 10-13 (1984) 
25. Taylor, A.: Linking Architecture and Education: Sustainable Design of Learning Environments. University of New Mexico Press (2009)

26. Hawkes, D.: The Enviromental Tradition: Studies in the Architecture of Environment, 1st edn. E \& FN Spon, London (1996)

27. Quan, S.J., Economou, A., Grasl, T., Yang, P.P.-J.: Computing energy performance of building density, shape and typology in urban context. Energy Proced. 61, 1602-1605 (2014)

28. Zhang, A., Bokel, R., van den Dobbelsteen, A., Sun, Y., Huang, Q., Zhang, Q.: The effect of geometry parameters on energy and thermal performance of school buildings in cold climates of China. Sustainability 9, 1708-1727 (2017)

29. Dogan, T., Reinhart, C., Michalatos, P.: Automated multi-zone building energy model generation for schematic design and urban massing studies. In: Presented in IBPSA eSim Conference, Ottawa, Canada (2014)

30. Erhorn-Kluttig, H., Erhorn, H.: School of the future- - towards zero emission with high performance indoor environment. Energy Proced. 48, 1468-1473 (2014)

31. Kats, G.: Greening America's schools: costs and benefits. www.usgbc.org/ShowFile.aspx? DocumentID=2908 (2006). Accessed 30 Oct 2008

32. EU Directive 2002/91/EC of the European parliament and of the council of 16 December 2002 on the energy performance of buildings. Off. J. Eur. Union 65-71 (2002). https://doi.org/10. 1039/ap9842100196

33. EU Directive 2012/27/EU of the European parliament and of the council of 25 October 2012 on energy efficiency. Off. J Eur. Union Dir. 1-56 (2012). https://doi.org/10.3000/19770677.L_ 2012.315.eng

34. EU Directive 2018/844 of the European parliament and of the council of 30 May 2018 amending directive 2010/31/EU on the energy performance of buildings and directive 2012/27/EU on energy efficiency

35. Krawczyk, D.A.: Theoretical and real effect of the school's thermal modernization-a case study. Energy Build. 81, 30-37 (2014)

36. Balogun, A.A., Morakinyo, T.E., Adegun, O.B.: Effect of tree-shading on energy demand of two similar buildings. Energy Build. 81, 305-315 (2014)

37. Dias Pereira, L., Raimondo, D., Corgnati, S.P., Gameiro Da Silva, M.: Energy consumption in schools - a review paper. Renew. Sustain. Energy Rev. 40, 911-922 (2014)

38. Facility Planning and Architecture Section. Architectural Design Guidelines for Schools. http://www.infrastructure.alberta.ca/content/doctype486/production/architecturalguidelines. pdf (2012)

39. Garwood, T.L., Hughes, B.R., Oates, M.R., O’Connor, D., Hughes, R.: A review of energy simulation tools for the manufacturing sector. Renew. Sustain. Energy Rev. 81, 895-911 (2018) 